\title{
EMPOWERMENT OF BUSINESS SERVICE COOPERATIVES PASIR BATANG SEJAHTERA IN CREATIVE ECONOMIC DEVELOPMENT OF THE COFFEE SECTOR, KARANGSARI VILLAGE, KUNINGAN REGENCY
}

\author{
Ine Mariane ${ }^{1}$, Aswin Palls ${ }^{2}$, Andre Ariesmansyah ${ }^{3}$ \\ ${ }^{1,2,3}$ Pasundan University, Jl. Lengkong Besar 68, Bandung, Indonesia \\ Ine.mariane@unpas.ac.id., \\ andre.ariesmansyah@unpas.ac.id.,aswin.palls@unpas.ac.id
}

\begin{abstract}
Cooperatives are an important part of the nation's economic system which is believed to be a financial institution that favors the weak economic group, and is one of the spearheads of the people's economy in accordance with Article 3 of the Cooperative Law Number 25 of 1992. Kuningan has 570 cooperatives, but only 440 cooperatives have a healthy status. The remaining 170 cooperatives are in a vacuum. The Pasir Batang Sejahtera Multipurpose Services Cooperative is one of the cooperatives engaged in all-round business services which includes the following business units: Coffee cultivation and processing services, Tourism Management Services, Agro Business Processing Services (agriculture, animal husbandry) and Community Empowerment Services consisting of the people of Karangsari Village, Darma District, Kuningan Regency and surrounding areas. Cooperatives are one of the sectors that have most felt the impact of the Corona Virus (Covid-19) outbreak, including the Pasir Batang Sejahtera Multipurpose Services Cooperative experiencing problems. Limited human resources, especially understanding of the management of cooperatives in the tourism sector, do not yet have a business network or partnership (Policy). Network) to develop existing business potential and problems that have not been able to respond to changes, especially changes in the market environment during the COVID-19 pandemic, which must follow health protocols. The approach method used in the Community Empowerment Program is as follows: 1. Training, which includes MSME management and networking, as well as analysis of market destinations and digital marketing in supporting tourism promotion 2. Mentoring,
\end{abstract}

Keywords: Management, Policy Network and Creative Economy Development

\section{A. Introduction}

Cooperatives are an important part of the nation's economic system which is believed to be a financial institution that favors the weak economic group, and is one of the spearheads of the people's economy which is expected to reduce economic inequality, alleviate poverty and improve the economic standard of the community. This is in accordance with Article 3 of the Cooperative Law Number 25 of 1992. Kuningan has 570 cooperatives, but cooperatives with 
healthy status only 440 cooperatives and the remaining 170 cooperatives are in a vacuum. The Pasir Batang Sejahtera Multipurpose Services Cooperative is one of the cooperatives engaged in all-round business services which includes the following business units:. Coffee cultivation and processing services, Tourism Management Services, Agro Business Processing Services (agriculture,

The multi-purpose service cooperative of Pasir Batang Sejahtera is one of the sectors most affected by the Corona Virus (Covid-19) outbreak, facing priority problems as MSME business actors, namely: 1. Policy Network problems or policy networks in terms of determining joint commitments to achieve goals in developing the potential of existing businesses, limited facilities and infrastructure to support tourism, as well as capital difficulties. 2. Management problems: Do not have proper management skills such as planning, organizing, supervising and controlling. 3. Problems with the application of creative economy and digital marketing technology include: Not being able to respond to changes, especially marketing promotions during the COVID-19 pandemic, which must follow health protocols.

Solutions offered 1. Problems with Policy Network Development Partners both to the Regional Government as well as business networks in the form of developing (designing) Business Partnership networks 2. Problems in Management of Training, mentoring and BIMTEK to increase Organizational and Management capacity 3. Problems with the Creative Economy and Marketing Partners Creative Economy Development, Promotional Development / Promotional Media and digital marketing in the form of developing (designing) Online Media and Access to Clients / Prospective Customers and Business Partnership Mediation.

\section{B. Method of Implementation}

Based on the Solutions and Output Targets from the program implementation plan, the team determines the approach method and steps, as follows: a. Identification of Partner Problems This is the first step carried out by the proposing team to identify partner problems, then determine priority problems faced by 
partners. b. Design, Design is an activity of describing, planning and sketching or arrangement of several separate elements into a unified whole and functions as a system design in the form of a system flowchart, which is a graphic form tool that can be used to show the sequence -process sequence of the system. This stage includes designing the tools needed by partners according to the priority problem, namely digital marketing. c.

This activity aims to create something in several ways or steps that are in accordance with the object to be made. In this step is to create / process information systems for digital marketing. d. Operational Testing, Operational Testing is an action to implement and try out tools to be put into practice, tested and tested, to find out whether the results of making a digital marketing system are feasible or there are still obstacles or weaknesses. In this case, the technology produced by the proposing team has been tested in several places. And the results show satisfactory results. e. Training / Dissemination Methods, training methods, aimed at transferring knowledge and technology (Ipteks) in overcoming problems through increasing insight and understanding for partners. The implementation of the training was carried out in the Hall of the Pasir Batang Sejahtera Multipurpose Services Cooperative. The approach method is determined by the team to overcome the problems, and the solution achieves the output targets that have been set for Management Problems, namely: increasing the managerial capabilities of partners so that partners have high abilities in managing and running their businesses, partners are able to carry out business management correctly, partners have Clear plans and division of tasks as business guidelines.

To Get Opportunities and Partnership Networks Able to determine market opportunities regarding potential tourist destinations and Market/Business Networks, Partners are able to establish cooperation with other parties in providing supporting facilities and infrastructure, as well as capital. For the Application of Technology Products, Partners will get digital marketing technology from the Design and Build Results of the Proposing Team; The Promotion Process is More Effective and able to increase Partner's 
Ability/Skill; Digitally promoted

Tourist Destinations can increase to ; Increased Marketing. f. The Technical Guidance and Operational Assistance Method, this Approach Method, is intended to transfer science and technology, so that both partners are able to practice the results of the training approach with Technical Guidance and Assistance from the experts (teams), Experts/Teams act in applicative ways to direct, guide processes and stages, set an example for Partners in overcoming problems and achieving targets and outcomes which include: Planning and division of tasks in managing cooperatives properly, as well as determining market opportunities and forming partnership networks to increase promotions tourist destinations by using digital marketing technology to partner groups $\mathrm{g}$. Facilitation and Mediation Approach Method This approach method is intended to simplify, lighten, expedite, connect, get, and have something that partners need. Facilitation and mediation approaches for partners are used in overcoming problems and achieving the following targets and outcomes: 1. Facilitation of Policy network improvement through partnerships with various parties to partners. 2. Facilitation and mediation of facilitation of access to customers and mediation of Business Networks for Partners.

\section{Result and Discussion}

Expected achievements of partners 1 . Networking development 1. Partners are able to determine market opportunities regarding potential tourist destinations and Market/Business Networks (80\%) 2. Partners are able to establish cooperation with local governments and private parties in business empowerment cooperatives (80\%) 3 . Increasing partner business networks (100\%) 6 2. Management problems 1. Partners are able to understand and have the right vision and mission of Cooperatives (100\%) 2. Partners understand and are able to create an effective organizational structure, distribution authority and have a clear Standard Operational Process (80\%) 3. Partner's abilities and skills have increased (80\%) 4. Partners understand and are able to plan, organize, control and supervise $(80 \%)$ 5. Partner's business becomes effective and efficient $(100 \%)$ Creative Economy 
and Digital Marketing Issues 1.Partners are able to take advantage of the creative economy sector in the coffee sector (80\%) 2. Partners are able to get Digital Marketing technology (80\%) 3 . Promotion process is more effective and able to increase $(80 \%) 4$. Marketing has increased (100\%). successfully achieved in a series of overall community service activities related to the Empowerment of the Pasir Batang Sejahtera Multipurpose Service Cooperative in the Creative Economy Development of the Coffee Sector in Karangsari Village, Kuningan Regency as follows:The outcomes that have been successfully achieved in a series of overall community service activities related to the Empowerment of the Pasir Batang Sejahtera Multipurpose Service Cooperative in the Development of the Creative Economy of the Coffee Sector, Karangsari Village, Kuningan Regency are as follows:The outcomes that have been successfully achieved in a series of overall community service activities related to the Empowerment of the Pasir Batang Sejahtera Multipurpose Service Cooperative in the Development of the Creative Economy of the Coffee Sector, Karangsari Village, Kuningan Regency are as follows:

\section{Outcomes for Partners}

\begin{tabular}{|c|c|c|}
\hline No. & $\begin{array}{c}\text { Training, Mentoring } \\
\text { and Technical Guidance }\end{array}$ & Outcomes for Partners \\
\hline 1 & $\begin{array}{l}\text { Correct Business Management } \\
\text { Capacity Improvement for } \\
\text { Partners }\end{array}$ & $\begin{array}{l}\text { - Organizational and management capacity } \\
\text { building } \\
\text { - Improvement of the organizational structure } \\
\text { of the all-round business service cooperative } \\
\text { of Pasir Batang Prosperous } \\
\text { - Development of human resource management } \\
\text { for members of the all-round service } \\
\text { cooperative of Pasir Batang Prosperous } \\
\text { - Increased motivation and creativity }\end{array}$ \\
\hline 2 & $\begin{array}{l}\text { Network Development } \\
\text { (Networking) }\end{array}$ & $\begin{array}{l}\text { Partners are able to design partnership } \\
\text { networks } \\
\text { Developing Partnership Network } \\
\text { Partnering with Regional Financial } \\
\text { Institutions }\end{array}$ \\
\hline 3 & $\begin{array}{l}\text { Partner's Creative Economy } \\
\text { Development }\end{array}$ & $\begin{array}{l}\text { Increasing the Creativity of Cooperative } \\
\text { Members } \\
\text { Partners can design digital marketing and }\end{array}$ \\
\hline
\end{tabular}




\begin{tabular}{|c|c|l|}
\hline No. & $\begin{array}{c}\text { Training, Mentoring } \\
\text { and Technical Guidance }\end{array}$ & \multicolumn{1}{c|}{ Outcomes for Partners } \\
\hline & & design Online Media \\
\hline
\end{tabular}

Solution Steps to Partner Priority Problems

Partner Priority Issues

1. Network

Development

2. Management Issues

3. Creative Economy

Problems and Digital

Problems

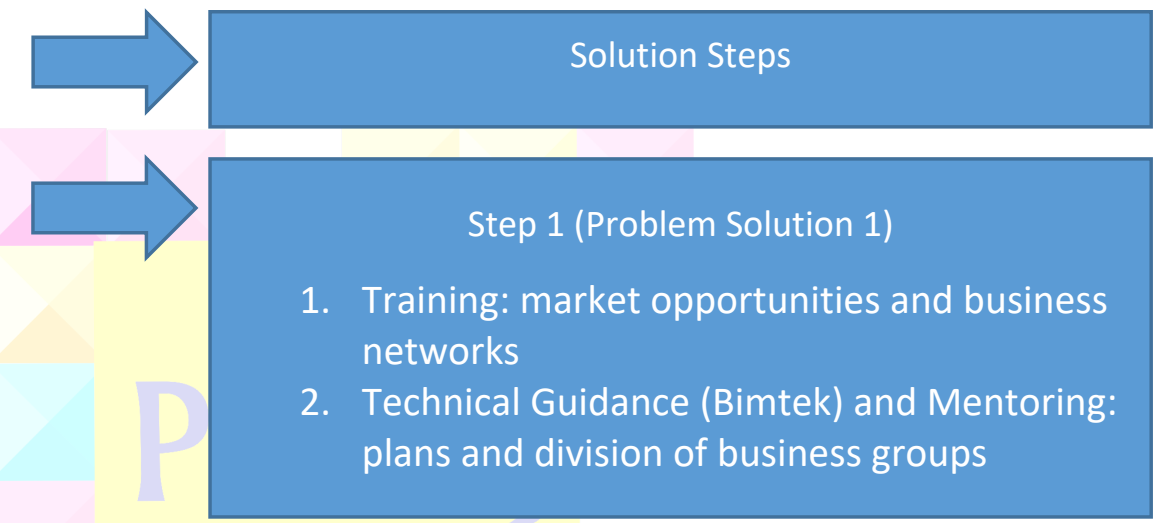

Step 2 (Problem Solution 2)

1. Training and Development of cooperative vision and mission

2. Training Effective organizational structure, division of authority

3. Training on making Standard Operational Process

Step 3 (Problem Solution 3)

1. Competitiveness and innovation improvement training

2. Digital Marketing Training (Promotional process flow and online promotional content creation) 


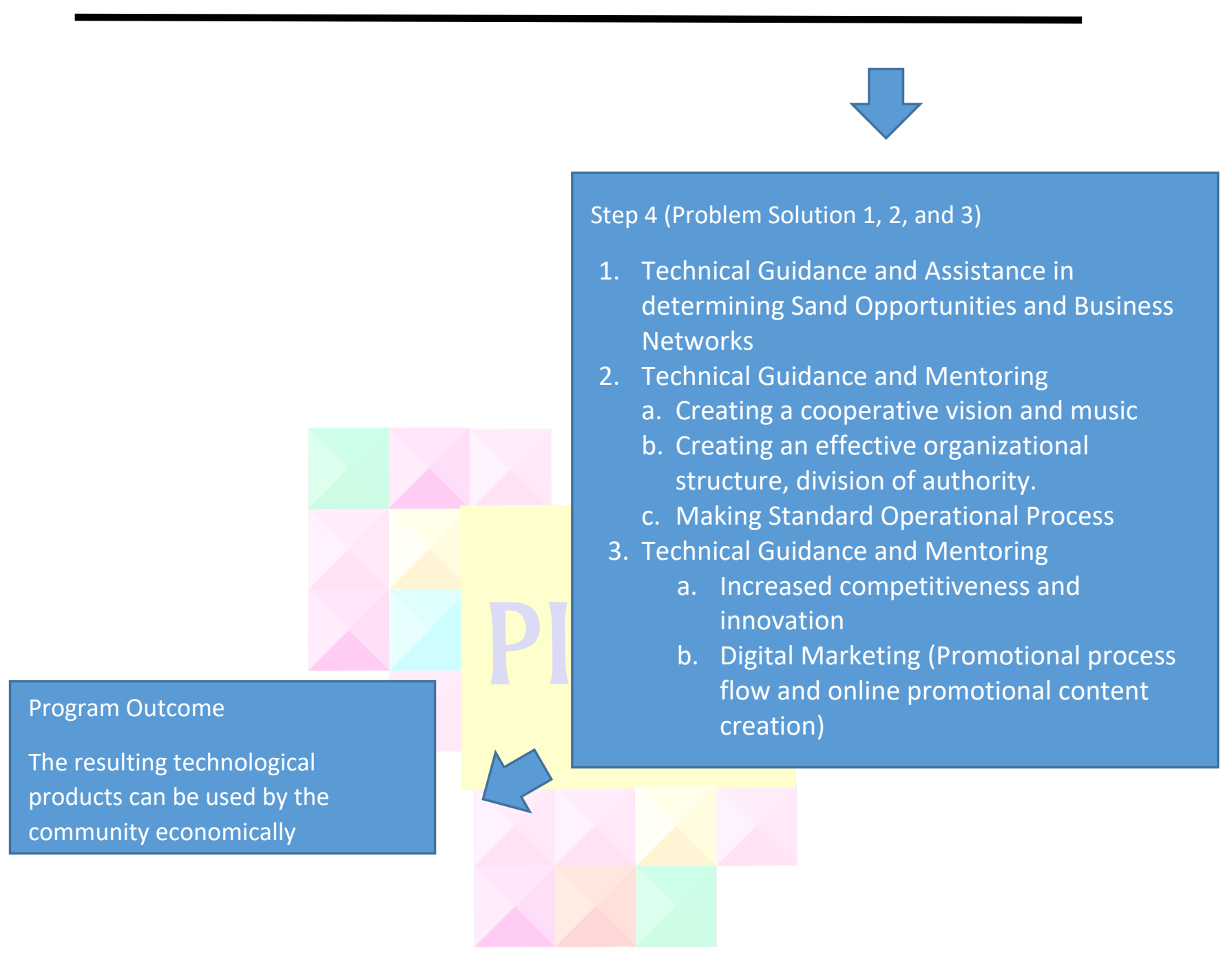




\section{Conclusion}

From the results of the training and technical guidance that has been carried out, it can be concluded that there are significant differences in terms of increasing the ability of the participants in choosing and using activities to describe, plan and sketch or arrange several separate elements into a single unit to solve a problem in partnerships that are able to establish cooperation with other parties in providing supporting facilities and infrastructure, as well as capital. the thing that is no less important is the problem of human resources running in it, therefore to face the development and progress of today's IT-based era,

\section{REFERENCES}

Atkinson, Michael and William Colleman, 1989, "Strong States and Weak States: Sectoral Policy Networks in Advanced Capitalist Economies", British Journal of Political Science.

Axelrod, R. 1997. The Complexity of Cooperation: Agent-Based Models of Competition and Collaboration. New Jersey: Princeton Univ. Press.

Birner, R., and H. Wittmer. 2003. Using Social Capital to Create Political Capital: How Do Local
Communities Gain Political Influence? A Theoretical Approach and Empirical Evidence from Thailand. In: Dolsak, N., and E. Ostrom (Eds.), The Commons in the New Millennium, Challenge and Adaptation. MIT Press, Cambridge and London, pp. 291334.

Carlsson, Lars, 2000, Policy Networks as Collective Action, Policy Studies Journal, Vol. 28, No. 3, p. 502-520.

Carlson, Lars. 2000. Policy Network as Collective Action, Policy Studies Journal, Vol. 28, No. 3: 502-520.

Coe, Benjamin P. 1992. "Progress Through Cooperation in a Rural Region". National Civic Review 81, (4):449-65.

Cooper, Donald R. and Pamela S. Schlinder. 2008. Business Research Methods. McGrawHill. New York.

Creswell, John W. 2004. Research Design: Qualitative, Quantitative, and Mixed Methods Approaches. London: SAGE Publications.

Fukuyama F. 1995. Trust: The Social Virtues and The Creation of Prosperity. New York: Free Press.

Graham, Grath, 2005, "Community Networking as Radical Practice", The Journal of Community 
Informatics, Vol. 1, No. 3, p. 111.

Grell, J. and Gary Gappert. 1993. The

New Civic Infrastructure:

Intersectoral Collaboration and the Decision-Making Process. National Civic Review 82(2):140148.

Hanf and FW Scharpf 1978. (eds) Interorganizational Policy Making. London: Sage. Hershberg, T., Pam Magidson, and Mary L. Werneeke. 1992. "Regional Promotion

Cooperation in Southeastern Pennsylvania". National Civic Review 81(4):418-34.

Hidayat, Aceng, 2007, Introduction to Institutional Economics, Course Modules, Department of Economic Resources and Environment, Bogor, FEM-IPB.

Hjern, B. and Porter, DO
1983.'Implementation

Structures: A New Unit for Administrative Analysis. Organizational Studies, 3 pp21137.

Howlett, Michael and M. Ramesh. 1995. Studying Public Policy: Policy Cycles and Policy Subsystems. Oxford University Press, Oxford.

Howlett, Michael and M. Ramesh. 1995. Studying Public Policy: Policy Cycles and Policy Subsystems. Oxford University Press, Oxford.

Huggins, M. 1992. "Momentum 21: Regional Cooperation in the Chippewa Valley". National Civic Review 81(4): 418-34.

Other sources:

Profile of the Pasir Batang

Multipurpose Services Cooperative

Cooperative. Prosperous 